UDC 614.777: 614.445

DOI: $10.21668 /$ health.risk/2016.4.08.eng

\title{
ESTIMATION OF RISK TO HEALTH OF THE POPULATION OF MINING TERRITORIES OF BASHKORTOSTAN CONNECTED WITH QUALITY OF DRINKING WATER SUPPLY
}

\author{
R.A. Suleimanov, A.B. Bakirov, T.K. Valeev, N.R. Rakhmatullin, \\ Z.B. Baktybaeva, R.A. Daukaev, N.N. Egorova
}

Ufa Research Institute of Occupational Health and Human Ecology, 94 Stepana Kuvykina Str., Ufa, 450106, Russian Federation

\begin{abstract}
The ecology-hygienic problems connected with quality of drinking water supply of the settlements, located on territories with the developed mining industry are considered in this article.

Poor quality of drinking water represents risk to health of the population and, according to the WHO's data, it provides the risk of occurrence of those or other diseases on $7 \%$. The mining enterprises are significant sources of pollution of objects of environment, including underground water horizons as their activity is interfaced to formation of great volumes of the waste containing zinc, copper, arsenic, lead, manganese, cadmium, mercury, chrome, etc. Morbidity of the population living in regions with the developed mining industry, is raised on the number of classes of illnesses and separate nosologies (illnesses of cardiocirculatory system, urinogenital system, organs of digestion, etc.).

The purpose of this research was carrying out of an estimation of quality of sources of drinking water supply and definition of an existing risk level to health of the population of mining territories with the subsequent development of hygienic recommendations and actions on optimization of conditions of water use. Hygienic researches are lead in settlements of mining territories of Republic Bashkortostan. Thirty settlements with the population of more than 200 thousand people were included into this research. The special attention was given to non-centralized sources of water supply (chinks, wells, springs) of mining territories used by inhabitants for the domestic and drinking purposes. It is established, that the qualitative structure of drinking water of investigated territories is characterized by the raised rigidity, the high concentration of iron, nitrates, chrome, cadmium. In separate territories of investigated region the unacceptable level of total olfactory risk, connected with the high concentration of iron and the raised rigidity of drinking water was revealed. Parameters of not cancerogenic risk, define high probability of development of a pathology from cardiovascular system, system of blood. The calculated levels of cancerogenic risks are estimated as unacceptable, testifying about existence of potential health hazard of the population.

Key words: the mining territories, not centralized water supply, quality of drinking water, hygienic researches, risk to health of the population, a level of cancerogenic and not cancerogenic danger, parameters of disease, priority polluting substances.
\end{abstract}

Introduction. People in some world regions, including Russia, have to use water

which doesn't correspond to hygienic standards. It causes substantial health risks and may

(C) Suleimanov R.A., Bakirov A.B., Valeev T.K., Rakhmatullin N.R., Baktybaeva Z.B., Daukaev R.A., Egorova N.N., 2016

Rafail A. Suleimanov - Doctor of Medical Science, Chief of Medical Ecology Department (e-mail: rafs52@ mail.ru; tel.: +7 (347) 255-46-21).

Akhat B. Bakirov - Academician of the Academy of Sciences of the Republic of Bashkortostan, Doctor of Medical Science, professor, director of the Institute (e-mail: fbun@ uniimtech.ru; tel.: +7 (347) 255-19-57).

Timur K. Valeev - PhD in Biological Science, Senior Researcher of Medical Ecology Department (e-mail: valeevtk2011@mail.ru; tel.: +7 (347) 255-46-21).

Nail R. Rakhmatullin - PhD in Biological Science, Senior Researcher of Medical Ecology Department (email: rnrnii2011@ mail.ru; tel.: +7 (347) 255-46-21).

Zulfiya B. Baktybaeva - PhD in Biological Science, Senior Researcher of Medical Ecology Department (e-mail: baktybaeva@ mail.ru; tel.: +7 (347) 255-46-21).

Rustem A. Daukaev - PhD in Biological Science, Head of Chemical and Analytical Department (e-mail: ufa.lab@yandex.ru.; tel.: +7 (347) 255-19-12).

Natalya N. Egorova - Doctor of Medical Science, a leading researcher at the Medical Ecology Department (e-mail: profanrb@gmail.com; tel.: +7 (347) 255-46-21). 
lead to certain diseases evolvement $[5,9,15-$ 17]. An issue of supplying qualitative drinking water to population in rural regions is particularly vital as $60 \%$ of decentralized water supply sources (wells and springs) do not conform to sanitary requirements.

Morbidity of population living in areas where mining industry is well-developed, both in Bashkortostan and Russian as a whole, exceeds average country levels for a number of diseases categories and certain nosologies. The analysis of data and parameters provided by Federal Information Fund for Social and Hygienic Monitoring showed that Republic of Bashkortostan was a risk territory as per overall morbidity level of adult population, digestive organs diseases, urogenital system diseases, and respiratory organs diseases [6]. Circulatory system diseases, urogenital system diseases, and digestive organs diseases are the most significant nosologies in the overall morbidity structure for population living in the examined areas in Bashkortostan as their levels exceed average morbidity levels detected in the republic. Overall morbidity of adult population living in south-eastern regions of Bashkortostan authentically exceeds average republic levels, both in general and in neoplasms category $[2,12]$.

Anthropogenic and technogenic load which occurs on urbanized and rural areas is characterized by a multi-environment influence and a great variability in levels of basic environmental factors [4]. Mining areas in south-eastern regions of Bashkortostan are influenced by a complex of hazardous technogenic and environmental factors. More than 1 billion tons of wastes have been accumulated on territories belonging to mining enterprises in Bashkortostan; such wastes include offgrade ores and barren rocks (Baimakskiy coppersulfur works has accumulated about 500 million tons; Uchalinskiy ore mining and processing works, about 300 million tons; Buribaevskiy ore mining and processing works, about 10 million tons etc.). Wastes of such enterprises contain heavy metals, such as zinc, copper, arsenic, lead, manganese, cadmium, mercury, chromium, etc. Average annual vol- ume of wastes generated by mining industry amounts to $44 \%$ of overall wastes volume in the whole republic $[10,13]$. Such a considerable volume of wastes accumulated on limited areas causes tense ecologic situation there where mining enterprises are located as well as beyond boundaries of their location. Regular manufacturing activities performed by mining enterprises exert additional negative influence on environmental objects, including underground water horizons which serve as drinking water supply sources for population [3, 13, $14]$.

Besides, agricultural enterprises which are sufficiently developed in south-eastern regions of Bashkortostan also make their negative contribution into natural waters contamination. Agricultural production intensifies, large stock-rising complexes are built, soils are polluted with chemicals, and new agricultural processing enterprises are created; it all leads to natural waters contamination and to poorer ecological situation in the region in general [1].

Research goal: to assess quality of drinking water supply sources and to detect health risk level for population living in mining areas; to work out hygienic recommendations and measures aimed at water consumption optimization.

Research objects and methods. Hygienic research was performed in settlements located in mining areas of Bashkortostan, namely in Beloretskiy, Abzelilovskiy, Uchalinskiy, and Baimakskiy administrative districts. Research comprised 30 settlements with total amount of population equal to more than 200 thousand people. Samples taken from underground water sources were analyzed as per basic priority parameters characterizing water quality as per organoleptic, overall sanitary, and sanitarytoxicological hazardous properties (Testanalytical center of the Institute is accredited in the Russian Accreditation system as per its technical competence and independence; accreditation certificate No. ROSS RU. 0001.510411 is valid till July 26, 2018). When we conducted our own research we paid special attention to decentralized water supply 
sources (wells and springs) which were used by people living in mining areas for their household activities. Risk analysis and calculation as per organoleptic parameters of underground waters quality was performed in full conformity with methodical guidelines [7]; carcinogenic and non-carcinogenic effects were estimated according to Guide [8]. When assessing actual contamination level for centralized water supply sources we also took data provided by laboratories of inter-district hygiene and epidemiology centers in Bashkortostan into account.

Research results and discussion. The accomplished examination of water samples taken from centralized water supply systems in main cities and district centers located on mining areas of Bashkortostan (Beloretskiy, Abzelilovskiy, Uchalinskiy, and Baimakskiy administrative districts) revealed that drinking water quality in general corresponded to hygienic requirements. Drinking water had aver- age hardness, contained a moderate amount of iron, zinc, copper, lead, manganese, chromium, cadmium, nitrates, sulfates, etc. It was also proved by the research data taken from laboratories of Hygiene and Epidemiology Center inter-district branches.

Certain rural areas in the examined region had no centralized water supply systems at all or they had such systems only partly; people living in such areas used alternative water sources (wells and springs) for their household needs.

Examination of water taken from decentralized water supply sources revealed that drinking water quality didn't conform to hygienic requirements in certain areas. The most significant water contamination parameters were increased hardness, high content of iron, calcium, and nitrates, as well as cadmium and hexavalent chromium presence concentrations very close to maximum permissible levels (Table 1).

Table 1

Most significant parameters of underground drinking waters contamination in mining areas in Bashkortostan

\begin{tabular}{|l|c|c|c|c|c|}
\hline \multicolumn{1}{|c|}{ Parameters } & MPC & \multicolumn{3}{|c|}{ Maximum values of parameters concentrations on certain areas } \\
\cline { 2 - 6 } & & $\begin{array}{c}\text { Uchalinskiy dis- } \\
\text { trict }\end{array}$ & $\begin{array}{c}\text { Beloretskiy dis- } \\
\text { trict }\end{array}$ & $\begin{array}{c}\text { Baimakskiy dis- } \\
\text { trict }\end{array}$ & $\begin{array}{c}\text { Abzelilovsliy } \\
\text { district }\end{array}$ \\
\hline Iron, mg/l & 0.30 & 0.35 & 1,80 & 0,56 & 0,30 \\
\hline $\begin{array}{l}\text { Chromium (VI), } \\
\text { mg/l }\end{array}$ & 0.05 & 0.05 & 0,05 & 0,03 & 0,05 \\
\hline Cadmium, mg/l & 0.001 & 0.001 & 0,001 & 0,0008 & 0,001 \\
\hline Calcium, mg/l & - & 156.3 & 120,2 & 220,5 & 170,3 \\
\hline Hardness, $^{\circ}$ \% & $7-10$ & 9.5 & 14,0 & 16,3 & 13,5 \\
\hline Nitrates, mg/l & 45 & 48 & 33 & 112 & 56 \\
\hline
\end{tabular}

Table 2

Calculation results for organoleptic risk of water taken from a well located in village of Halilovo, Baimakskiy district, Bashkortostan

\begin{tabular}{|l|c|c|c|}
\hline \multicolumn{1}{|c|}{ Analyzed parameter } & $\begin{array}{c}\text { Value } \\
\text { (concentration) }\end{array}$ & Prob & Risk \\
\hline Manganese & 0.04 & -3.321 & 0.0005 \\
\hline Copper & 0.01 & -8.645 & $2.80 \mathrm{E}-18$ \\
\hline Iron (total) & 0.56 & -1.100 & $\mathbf{0 . 1 3 6}$ \\
\hline Chlorides & 91.2 & -3.939 & $4.09 \mathrm{E}-05$ \\
\hline Overall mineralization & 1261 & -1.665 & 0.048 \\
\hline Overall hardness & 16.3 & -0.781 & $\mathbf{0 . 2 1 7}$ \\
\hline Maximum value & - & -0.781 & 0.217 \\
\hline
\end{tabular}


Table 3

Non-carcinogenic risk related to water consumption in some settlements of Baimakskiy district, Bashkortostan

\begin{tabular}{|l|c|c|c|c|c|c|}
\hline Organs and systems & Bogachevo & Karatamak & Tavyikaevo & Yulyik & $\begin{array}{c}\text { Verkhne- } \\
\text { Yakibaevo }\end{array}$ & Saigafar \\
\hline $\begin{array}{l}\text { Central nervous sys- } \\
\text { tem }\end{array}$ & 0.02 & 0.08 & 0.07 & 0.09 & 0.05 & 0.05 \\
\hline $\begin{array}{l}\text { Cardiovascular sys- } \\
\text { tem }\end{array}$ & $\mathbf{3 . 0 0}$ & $\mathbf{1 . 3 5}$ & $\mathbf{2 . 5 3}$ & $\mathbf{2 . 0 9}$ & $\mathbf{1 . 9 0}$ & $\mathbf{3 . 0 0}$ \\
\hline Blood system & $\mathbf{3 . 0 3}$ & $\mathbf{1 . 3 5}$ & $\mathbf{2 . 5 3}$ & $\mathbf{2 . 0 9}$ & $\mathbf{1 . 9 0}$ & $\mathbf{3 . 0 0}$ \\
\hline Immune system & 0.014 & 0.003 & 0.003 & 0.007 & 0.010 & 0.016 \\
\hline Reproductive system & 0.026 & 0.16 & 0.174 & 0.15 & 0.11 & 0.033 \\
\hline Gastrointestinal tract & 0.43 & 0.04 & 0.037 & 0.028 & 0.018 & 0.042 \\
\hline Kidneys & 0.63 & 0.18 & 0.23 & 0.20 & 0.10 & 0.28 \\
\hline Liver & 0.43 & 0.04 & 0.037 & 0.028 & 0.018 & 0.042 \\
\hline Skin & 0.05 & 0.05 & 0.03 & 0.16 & 0.018 & 0.08 \\
\hline Hormonal system & 0.12 & 0.20 & 0.21 & 0.21 & 0.12 & 0.05 \\
\hline $\begin{array}{l}\text { Biochemical parame- } \\
\text { ters }\end{array}$ & 0.11 & 0.27 & 0.33 & 0.25 & 0.17 & 0.25 \\
\hline Mucous tunics & 0.48 & 0.08 & 0.06 & 0.19 & 0.03 & 0.10 \\
\hline Development & 0.012 & 0.16 & 0.171 & 0.14 & 0.10 & 0.017 \\
\hline
\end{tabular}

Content of arsenic, lead, strontium, silver, copper, zinc, aluminum, manganese, nickel and other metals in drinking waters didn't exceed sanitary-hygienic standards in any settlement. We should note that we detected general coliform and thermo-tolerant coliform bacteria in water taken from water supply sources in some settlements; such water is dangerous to drink as per epidemiologic parameters.

Analysis of actual fluoride-ions concentrations was also a significant criterion used in drinking water quality assessment. The research showed that fluoride-ions content in water taken from centralized water supply system was within $0.01-0.25 \mathrm{mg} / \mathrm{l}$ range, and within 0.01 $0.12 \mathrm{mg} / \mathrm{l}$ range for decentralized water supply sources. We should note that underground waters used for centralized and decentralized water supply system on most territories of Beloretskiy, Abzelilovskiy, Uchalinskiy, and Baimakskiy administrative districts cannot be considered physiologically full-fledged as they contain less than $0.3 \mathrm{mg} / \mathrm{l}$ fluorine and are classified as water sources with low fluorine con- tent. The detected fluorine deficiency can cause increased morbidity in teeth caries and it may contribute into certain chronic septic and rheumatoid diseases evolvement.

When assessing organoleptic risk, we determined priority parameters rated as per their influence on organoleptic water properties; these parameters included manganese, copper, overall iron, chlorides, as well as such aggregated parameters as overall mineralization and hardness. According to MG [7], overall organoleptic risk is estimated via choosing its maximum value out of all values characterizing each parameter. Acceptable risk value for reflexolfactory hazardous effects amounts to 0.1 (or $10 \%)$.

As calculation results revealed, unacceptable level of total organoleptic risk occurred on certain territories of the examined region; this risk was related to high iron contents and increased hardness of drinking water. For example, risk parameters values for water taken from a well located in village of Halilovo amounted to 0.1365 as per iron content, and 0.217 as per 
hardness, and such organoleptic risk level can be classified as unacceptable according to $\mathrm{MG}$ [7] (Table 2).

Similar results were obtained in other settlements, namely V.Avzyan, Utkalyovo, and Buganak villages (Beloretskiy district), "Yuzhniy" microdistrict of Uchaly city (Uchalinskiy district), Tavyikaevo and Bogachevo villages (Baimakskiy district), Novobalanovo and Baimovo villages (Abzelilovskiy district).

The obtained results of non-carcinogenic risk assessment for risks related to drinking water consumption revealed that people living in some settlements of the examined region ran the risk of pathologies evolving in cardiovascular system (hazardous indexes (HI) amounted to 1.01-5.46) related to increased nitrates content in water, and in blood system (HI amounted to 1.01-5.66) related to nitrates, manganese, iron, and lead content.

The most unfavorable situation was detected in Baimakskiy district, in Bogachevo village (HI amounted to 3.0-3.03), Karatamak village (HI amounted to 1.35), Nizhnee Idrisovo village (HI amounted to 2.22), Tavyikaevo village (HI amounted to 2.53), Yulyik village (HI amounted to 2.09), Verkhneyaikbaevo and Ishmukhametovo villages (HI amounted to 1.90), Saigafar village (HI amounted to 3.0) (Table 3).

High non-carcinogenic risk levels were also detected on other areas, namely in Yuldashevo village (HI amounted to 1.09-1.16), Saitakovo village (HI amounted to 5.46-5.66), Uchaly (HI amounted to 1.09-1.40) of Uchalinskiy district; Geologorazvedka vilalge (HI amounted to 1.21), Novobalanovo village (HI amounted to 0.93), Baimovo village (HI amounted to 1.02) of Abzelilovskiy district and in Ishlya village of Beloretskiy district (HI amounted to 1.01).

To assess carcinogenic health risk at oral introduction of substances with water we determined 4 substances with carcinogenic effects, namely cadmium, lead, hexavalent chromium, and benzpyrene. The examination revealed that total individual carcinogenic risk related to use of decentralized water supply sources by population living in the examined region exceeded 1,00E-03 on some territories; according to Guide [8], such risk level corresponds to the 4th category and is considered to be unacceptable, both for population and professional groups. Such high carcinogenic risks level was registered in certain settlements in Beloretskiy district (it was 1.14E-03 in Slantsyi village, $1.00 \mathrm{E}-03$ in Azikeevo village) and $\mathrm{Ab}$ zelilovskiy district (baimovo and Tashbulatovo villages, 1.00E-03). Carcinogenic risk on these territories was caused by chromium content (3.4E-04 - 8.4E-04) and benzpyrene content (2.9E-04-6.6E-04) in water.

Decentralized water supply sources on most territories of Bashkortostan south-eastern region belonged to the 3rd category of the conventional risk levels classification (more than 1.0E-04, but less than 1.0E-03) characterized as "acceptable for professional groups but unacceptable for population in general". Chromium, benzpyrene, and lead were the main components causing increased carcinogenic risk.

The most favorable situation characterized with maximum permissible level of carcinogenic risk (less than 1.0E-04) was detected in Uchalinskiy district (in Burantsy village, Uchalyi city, Il'chino village), and in Baimakskiy disrict (in Halilovo and Isyanovo villages).

Population carcinogenic risk as a number of additional malignant neoplasms cases for overall population number on the examined territories amounted to 119.02 cases in Beloretskiy district (population amounts to 104,401 people); 61.04 cases, in Uchalinskiy district (72,663 people); 45.04 cases, in Abzelilovskiy district (45,042 people): 10.02 cases, in Baimakskiy district (57,283 people).

Conclusion. Water from centralized water supply sources in main cities and district centers in Bashkortostan mining regions in general conforms to sanitary and hygienic standards. Yet, quality of decentralized water sources doesn't conform to the existing requirements on some territories. The results of drinking water samples analysis revealed that in case of decentralized water supply on mining territories such contamination parameters as increased hardness, high content of iron, calcium, nitrates, as well as hexavalent chromium content in con- 
centrations close to maximum permissible ones, are top water contamination parameters.

We detected high nitrates content in drinking waters taken from wells and springs on some territories. Besides, we found coliform and thermo-tolerant coliform bacteria in water taken from wells and springs used by population for household needs.

Assessment of organoleptic, noncarcinogenic and carcinogenic risks caused by drinking water consumption in some mining areas in Bashkortostan showed that water sources may really have some influence on population living conditions and health state in this region.

Population in mining areas of Bashkortostan who use decentralized water supply sources may actually run the risk of malignant neoplasms evolvement. The highest carcinogenic risk (up to 10-12 additional malignant neoplasms cases per 10,000 people) may occur on some territories of Beloretskiy district (Slantsyi and Azikeevo villages) and Abzelilovskiy district (Baimovo and Tashbulatovo villages). Carcinogenic risk which may occur on these territories is caused by increased hexavalent chromium and benzpyrene content in water. The most favorable situation with low carcinogenesis probability was forecasted In Uchalinskiy and Baimakskiy districts, in billages halilovo, Burantsyi, Il'chino and Isyanovo.

Besides, population on the examined territories may also run the risk of pathologies evolvement in blood system caused by increased nitrates, manganese, iron and lead con- tent in water, and in cardiovascular system caused by increased nitrates content in water. We also detected significantly high (signal) hazardous indexes values which may lead to pathological changes in gastrointestinal tract, kidneys, and other organs and systems.

The obtained results coincide with other authors' research $[2,4,5,10,11,14,15]$. We should note that chemical and analytical data are not sufficient and representative enough and this fact influences the final assessment reliability; also only a part of impurities present in drinking water were included into monitoring examinations. Since risk assessment was performed as if for a maximum exposed individual (who was theoretically exposed to maximum possible impact exerted by contaminated drinking water during his lifetime), and all obtained values exceed acceptable risk levels we assume that it may be appropriate to conduct expanded research basing on data on actual exposure loads which population in mining areas in Bashkortostan may suffer from. Besides, one should detect a relative contribution made by each water supply source into risk of carcinogenic and non-carcinogenic diseases in order to create most favorable conditions for further risk management.

This research results were used to work out a system of recommendations on providing population in rural settlements with good quality drinking water, improving their social and hygienic living conditions, and reducing morbidity caused by water factor.

\section{References}

1. Abdrakhmanov R.F. Gidrogeoekologiya Bashkortostana [Hydrogeoecology of Bashkortostan]. Ufa, Informreklama Publ., 2005, 344 p. (in Russian).

2. Askarov R.A. Otsenka riska zdorov'iu naseleniia gornodobyvaiushchego regiona pri vozdeistvii kompleksa khimicheskikh faktorov okruzhaiushchei sredy [The assessment of health risk to the population of the mining region under the influence of complex chemical environment]. Meditsinskii vestnik Bashkortostana, 2011, no. 1, pp. 20-24 (in Russian).

3. Dunaev V. N., Boev V.M., Shageev R.M., Frolova E.G. Gigienicheskaia otsenka formirovaniia riska zdorov'iu pri vozdeistvii metallov i ikh soedinenii [Hygienic estimation of formation of health risk in case of exposure to metals and metal compounds]. Vestnik Orenburgskogo gosudarstvennogo universitet, 2006, vol. 62, no. 12-2, pp. 89-92 (in Russian).

4. Zaitseva N.V., May I.V., Balashov S.Ju. Mediko-biologicheskie pokazateli sostojanija zdorov'ja naselenija $\mathrm{v}$ uslovijah kompleksnogo prirodno-tehnogennogo zagrjaznenija sredy obitanija [Medical and biologic parameters of the population health state in conditions of inhabitancy complex natural- 
technogenic pollution]. Izvestija Samarskogo nauchnogo centra Rossijskoj akademii nauk, 2009, vol. 11, no. 1-6, pp. 1144-1148 (in Russian).

5. Pozdniakova M.A., Fedotova I.V., Lipshits D.A., Koroleva T.A. Innovacionnaja statisticheskaja metodika ocenki kachestva pit'evogo vodosnabzhenija kak instrument sistemy upravlenija riskami zdorov'ju naselenija [The innovation statistical methods of the assessment of the quality of drinking water supply as an instrument of control system of the risks to the public health]. Medicinskij al'manah, 2011, no. 3, pp. 37-39 (in Russian).

6. Kon'shina L.G., Lezhnin V.L. Otsenka kachestva pit'evoi vody i riska dlia zdorov'ia naseleniia [Assessment of the quality of drinking water in the industrial city and risk for public health]. Gigiena $i$ sanitariia, 2014, no. 3, pp. 5-10 (in Russian).

7. MR 2.1.4.0032-11. Integral'naia otsenka pit'evoi vody tsentralizovannykh sistem vodosnabzheniia po pokazateliam khimicheskoi bezvrednosti: Metodicheskie rekomendatsii. Federal'nyi tsentr gigieny i epidemiologii Rospotrebnadzora, 2011, 37 p. (in Russian).

8. Valeev T.K., Suleimanov R.A., Egorova N.N., Daukaev R.A., Rakhmatullin N.R., Allaiarova G.R. Materialy ekologo-gigienicheskikh issledovanii kachestva vodnykh ob"ektov na territoriiakh gornorudnogo raiona [Environmental and health studies data of water quality across the territories of mining area]. Voda: khimiia i ekologiia, 2015, no. 3, pp. 30-33 (in Russian).

9. Rafikova Iu.S., Semenova I.N., Seregina Iu.Iu., Khakimzianov O.M. Mediko-ekologicheskie osobennosti gornorudnykh regionov Zaural'ia Respubliki Bashkortostan [Health-environmental characteristics of the mining regions of the Ural region the Republic of Bashkortostan]. Fundamental'nye issledovaniia, 2012, no. 11-1, pp. $43-45$ (in Russian).

10. O sostojanii sanitarno-jepidemiologicheskogo blagopoluchija naselenija v Rossijskoj Federacii v 2015 godu: Materialy k gosudarstvennomu dokladu po Respublike Bashkortostan [On the state of sanitary and epidemiological welfare of the population in the Russian Federation in 2015: Contributions to the state report of the Republic of Bashkortostan]. Ufa, Upravlenie Federal'noj sluzhby po nadzoru v sfere zashhity prav potrebitelej i blagopoluchija cheloveka po Respublike Bashkortostan, Centr gigieny i jepidemiologii $\mathrm{v}$ Respublike Bashkortostan Publ., 2016, 291 p. (in Russian).

11. Suleimanov R.A., Allaiarova G.R., Karimova L.K., Valeev T.K., Daukaev R.A. Organizatsiia sistemy sotsial'no-gigienicheskogo monitoringa na territoriiakh s razvitoi gornorudnoi promyshlennost'iu Respubliki Bashkortostan [Organization of a sociohygienic monitoring system in the developed oremining areas of the Republic of Bashkortostan]. Gigiena i sanitariia, 2008, no. 1, pp. 84-87 (in Russian).

12. Teregulova Z.S., Belan L.N., Askarov R.A., Teregulova Z.F., Altynbaeva A.I. Osobennosti zagriazneniia sredy obitaniia i zabolevaemost' naseleniia $\mathrm{v}$ gornodobyvaiushchem regione Respubliki Bashkortostan [Specificities of environmental pollution and health disorders of the ore-mining region population]. Meditsinskii vestnik Bashkortostana, 2009, no. 6, pp. 20-25 (in Russian).

13. Rukovodstvo po ocenke riska dlja zdorov'ja naselenija pri vozdejstvii himicheskih veshhestv, zagrjaznjajushhih okruzhajushhuju sredu R 2.1.10.1920-04 [Guide to health risk assessment when exposed to chemicals polluting the environment 2.1.10.1920-04 P]. Moscow, Federal'nyj centr Gossanjepidnadzora Minzdrava Rossii Publ., 2004, 143 p. (in Russian).

14. Semenova I.N., Rafikova Ju.S., Il'bulova G.R. Vozdejstvie predprijatij gornorudnogo kompleksa Bashkirskogo Zaural'ja na sostojanie prirodnoj sredy i zdorov'e naselenija prilegajushhih territorij [The impact of mining complex enterprises of the Bashkir Trans-Urals on the state of the environment and the health of the population of the surrounding areas]. Fundamental'nye issledovanija, 2011, no. 1, pp. 29-34 (in Russian).

15. Suleimanov R.A., Baktybaeva Z.B., Khanturina G.R., Seitkasymova G.Zh., Valeev T.K., Rakhmatullin N.R. Ekologo-gigienicheskaia otsenka sostoianiia vodnykh resursov gornorudnykh territorii respublik Bashkortostan i Kazakhstan [Ecological and hygienic assessment of water resources in the mining areas of the republics of Bashkortostan and Kazakhstan]. Meditsina truda i ekologiia cheloveka, 2016, no. 1, pp. 16-20 (in Russian).

16. Anneclaire J. De Roos, Mary H. Ward. Drinking Water and Cancer. Epidemiology, 2004, vol. 15, no. 3, pp. 378-380.

17. Sohel N., Persson L.A., Rahman M., Streatfield P.K., Yunus M., Ekstrom E.C., Vahter M. Arsenic in drinking water and adult mortality: a population-based cohort study in rural Bangladesh. Epidemiology, 2009, vol. 20, no. 6, pp. 824-830.

18. Chung Y., Beck Y.S., Beck Y.M. Risk Assessment of Drinking Water Pollutants. Epidemiology, 2006, vol. 17 , no. 6 , pp. 331 . 
Suleimanov R.A., Bakirov A.B., Valeev T.K., Rakhmatullin N.R., Baktybaeva Z.B., Daukaev R.A., Egorova N.N. Estimation of risk to health of the population of mining territories of Bashkortostan connected with quality of drinking water supply. Health Risk Analysis, 2016, no. 4, pp. 58-65. DOI: 10.21668/health.risk/2016.4.08.eng

Received: 24.08.2016

Accepted: 19.12 .2016

Published: 30.12 .2016 